\section{Association between particulate matter air pollution and monthly inhalation and nebulization procedures in Ribeirão Preto, São Paulo State, Brazil}

\author{
Associação entre a poluição atmosférica por \\ material particulado e contagens mensais de \\ procedimentos de inalação e nebulização \\ em Ribeirão Preto, São Paulo, Brasil
}

Estela Cristina Carneseca 1

Jorge Alberto Achcar 1

Edson Zangiacomi Martinez 1
1 Faculdade de Medicina de Ribeirão Preto, Universidade de São Paulo, Ribeirão Preto, Brasil.

Correspondence E. Z. Martinez

Faculdade de Medicina de Ribeirão Preto, Universidade de São Paulo.

Av. Bandeirantes 3900 ,

Ribeirão Preto, SP

14049-900, Brasil.

edson@fmrp.usp.br

\section{Abstract}

The study was designed to investigate the impact of air pollution on monthly inhalation/ nebulization procedures in Ribeirão Preto, São Paulo State, Brazil, from 2004 to 2010. To assess the relationship between the procedures and particulate matter $\left(P M_{10}\right)$ a Bayesian Poisson regression model was used, including a random factor that captured extra-Poisson variability between counts. Particulate matter was associated with the monthly number of inhalation/nebulization procedures, but the inclusion of covariates (temperature, precipitation, and season of the year) suggests a possible confounding effect. Although other studies have linked particulate matter to an increasing number of visits due to respiratory morbidity, the results of this study suggest that such associations should be interpreted with caution.

Air Pollution; Particulate Matter; Respiratory Tract Infections

\section{Introduction}

Factors that influence a population's health conditions include climate changes 1,2 and atmospheric conditions 3,4. In Brazil, research on this theme has grown in recent years 5,6,7, and many studies have associated pollution and meteorological factors with respiratory diseases $8,9,10,11,12,13$. Such studies, when conducted in specific populations, can provide important descriptions of the occurrence of new cases of respiratory complications in a given period and their effect on spending by the public health system.

Ribeirão Preto is a municipality (county) with approximately 600,000 inhabitants located on a plateau in the North/Northeast region of the State of São Paulo. It belongs to the 13th Regional Health Department (DRS-XIII) of the State Health Secretariat, and $38.3 \%$ of the population are beneficiaries of the supplementary health system (covered by private health plans or insurance) ${ }^{14}$. Thus, the remaining $61.7 \%$ of the total population consists of persons that depend on the public Brazilian Unified National Health System (SUS).

The topography in Ribeirão Preto consists mainly of smooth slopes and rolling land, which favors mechanized agriculture. According to Köeppen's climatic classification 15, Ribeirão Preto has an Aw type climate, that is, wet tropi- 
cal with a dry winter and the coolest month with mean temperature greater than $18^{\circ} \mathrm{C} 16$. The satisfactory economic and social indicators in Ribeirão Preto result from a strong and diversified economic structure, both in the municipality and the region as a whole, thanks mainly to agriculture 17. The quality of the soil (red earth) and climate make it one of the leading agricultural areas in the State of São Paulo and Brazil as a whole, characterized by thriving farm production and high crop yields, especially for sugarcane, making the region the world's largest producer of sugar and alcohol. As a result, Ribeirão Preto suffers from intense environmental degradation due to burning of the cane fields by the sugarcane industry, which is extremely harmful to health 18,19 and identified as the principal source of air pollution.

An aggravating factor in the cane field burning is the so-called urban fires, very common in Ribeirão Preto during droughts and visible along sidewalks and in yards and lots, close to residential areas, places where anyone is readily exposed to the smoke, which is easily dispersed by the wind. In addition to releasing substances like carbon monoxide (CO), hydrocarbons, and methane, which cause and aggravate respiratory and cardiovascular diseases, the incomplete combustion of organic matter releases particulate matter, contained in both the smoke and soot 20 .

The term particulate matter (PM) refers to both solid particles and droplets dispersed in the air, and particles with an aerodynamic diameter from 2.5 to 10 microns are generally designated as $\mathrm{PM}_{10}$ or inhalable particles 21 . Both fine and heavier particles can accumulate in the respiratory system, while the thicker particles can aggravate preexisting respiratory problems, especially in children and elderly, increasing the risk of emergency hospitalization and premature death 22,23 . In this context, various studies have shown that the release of gases from burning organic matter increases the incidence of respiratory and cardiovascular diseases, and that substances resulting from burning of sugarcane contribute to the incidence and increase of respiratory tract diseases 18,23,24,25,26,27.

The current study aims to analyze the effects of exposure to inhalable particulate matter $\left(\mathrm{PM}_{10}\right)$ on the number of inhalation/nebulization procedures, considering that variations in the monthly numbers of these procedures may be related to adverse health events, mainly involving the respiratory tract.

\section{Methods}

This ecological time series study used monthly data on inhalation and nebulization procedures obtained from the Ambulatory Information System of the SUS (SIA/SUS) from January 2004 to December 2010, available on the DATASUS website (Data and Information Technology Department of the SUS). This information system classifies in a single group all the procedures that use some inhalation procedure, whether conventional nebulizers or the different types of inhalers 28 . Measurements of inhalable particulate matter $\left(\mathrm{PM}_{10}\right)$ were obtained from the Environmental Sanitation Technology Company (CETESB). Since there was only one air quality monitoring station in Ribeirão Preto, the data were not collected daily, but once or twice a week. Thus, the study uses the monthly mean $\mathrm{PM}_{10}$, taking the available values as representative of the respective month. Based on daily measurements for low temperature and precipitation, obtained from the Integrated Center for Agricultural and Meteorological Information (CIIAGRO) of the State of São Paulo, monthly averages were obtained for low temperature $\left({ }^{\circ} \mathrm{C}\right)$ and total monthly precipitation (mm).

A single step was used to obtain descriptive statistics for the air pollutant, low temperature, precipitation, and inhalation/nebulization procedures. In the data modeling, the number of monthly inhalation/nebulization procedures each month $\left(N_{i}\right.$, with the index $i$ associated with the respective month) was considered a dependent variable and the control variables were defined as the season of the year (coded as a dummy variable 29 ), monthly low temperature, and monthly precipitation.

The association between the monthly number of inhalation/nebulization procedures and particulate matter was estimated using a Poisson regression model 30 in a Bayesian approach 31 . The use of Poisson distribution is justified by the fact that the dependent variable $\left(N_{i}\right)$ is a counting event. The model is thus defined by

$P\left(N_{i}=n_{i} \mid \lambda_{i}\right)=\frac{e^{-\lambda_{i}} \lambda_{i}^{n_{i}}}{n_{i} !}, n_{i}=0,1,2, \ldots, i=1,2, \ldots, k$, where $N_{i}$ is the number of inhalations/nebulizations in the $i$ th month and $k$ is the number of months contained in the study period. Associated with each month, the following covariates were considered: monthly mean particulate matter $\left(X_{1 i}\right)$, mean particulate matter in the previous month $\left(X_{2 i}\right)$, low temperature $\left(X_{3 i}\right)$, precipitation $\left(X_{4 i}\right)$, and binary dummy variables 29 for the autumn, winter, and spring, respectively termed $X_{5 i}, X_{6 i}$, and $X_{7 i}$ (with summer thus considered a 
reference class). To connect the variables to the location parameter $\lambda_{i}$ from the Poisson distribution, the study considered the regression model $\lambda_{i}=h_{i} \exp \left(w_{i}\right)$, such that

$\eta_{i}=\exp \left\{\beta_{0}+\sum_{j=1}^{4} \beta_{j}\left(X_{j i}-\bar{X}_{j}\right)+\beta_{5} X_{5 i}+\beta_{6} X_{6 i}+\beta_{7} X_{7 i}+\beta_{8} t_{i}\right\}$, $\bar{X}_{j}$ is the mean of the (continuous) covariate $X_{j i}, j=1, \ldots, 4, i=1,2, \ldots, k$, and $w_{i}$ is a random effect responsible for capturing the extra-Poisson variability (overdispersion) and consequently improve the model's fit, considering that associated with each month there is an inhalation/nebulization rate that is associated with each month and that depends on external factors, difficult to be measured. Further, $\beta_{8}$ is a parameter whose function is to capture a temporal modification trend in the procedure counts, where $t_{i}, i=1,2, \ldots$, $k$, sequentially assumes integer values from $-k / 2$ to $(k / 2)-1$ (for even $k$ ). It was assumed that the random effect $w_{i}$ follows a normal distribution with mean 0 and unknown variance $s^{2}$.

The hierarchical Bayesian analysis considered two stages: the first stage assumed a priori Gaussian distributions for the parameters $\beta_{0}, \beta_{1}$, ..., $\beta_{7}$ and $\beta_{8}$ (with mean zero and large variances, with a magnitude of 10,000 , thus seeking some sense of non-information), and the second stage assumed an inverse gamma distribution with parameters 1 and 1 for $\sigma^{2}$. Using the OpenBugs software 32 , two million samples were obtained for each target parameter, while the first 20,000 samples were discarded to avoid any effect from the initial values. Samples were also selected for the inferences with size leaps of 500 in order to avoid correlations between successive samples. Convergence of samples was verified visually using autocorrelation graphs and tracings of the simulated samples. 95\% confidence intervals (95\%CI) were obtained for the parameters of interest. When the $95 \% \mathrm{CI}$ for a parameter $\beta_{1}$ to $\beta_{8}$ does not contain the value 0 , it suggests evidence of an effect by the respective variable on the monthly number of procedures (analogous to the interpretation of $\mathrm{p}<0.05$ in classical statistical methods). After adjusting models with different numbers of independent variables, comparisons were possible through DIC (deviance information criterion) values. Models with lower DIC values are considered to fit the data better.

\section{Results}

Figure 1 (top) shows the monthly number of inhalations/nebulizations in Ribeirão Preto from January 2004 to December 2010, plus time series for total monthly precipitation and monthly mean low temperature and $\mathrm{PM}_{10}$. Note that the time series for the number of procedures is discontinuous, with records missing for the months of July 2006 and January, April, and May 2008. Considering that for some reason there were no reports of inhalation/nebulization procedures in these months, their respective counts were estimated by the Bayesian procedure, considering missing data as parameters. Considering the entire study period, there was a monthly mean of 3,777 inhalations/nebulizations, with the lowest number recorded in November 2010 (936 procedures) and the highest in July 2004 (11,900 procedures). As shown in Figure 1, the number of inhalations/nebulizations decreased in the latter years of the study period. However, the data showed a seasonal trend, with more procedures from the months of May to October.

The time series depicted in Figure 1 show the seasonal behavior of total monthly precipitation and monthly mean low temperature and $\mathrm{PM}_{10}$ during the period and suggest an association with the number of inhalations/nebulizations. Particulate matter is released more frequently in the middle months of the year, coinciding with lower precipitation and lower temperatures, as well as with the most inhalation procedures. Thus, there were more inhalations in the autumn and winter (Table 1), times of the year in which sudden temperature changes alone are potential risk factors for respiratory problems, aggravated by inhalation of smoke and pollutants released by burning.

The monthly mean $\mathrm{PM}_{10}$ for the study period as a whole, $41.3 \mu \mathrm{g} / \mathrm{m}^{3}$, is below the reference value of the World Health Organization (WHO) 33 for 24-hour averages $\left(50 \mu \mathrm{g} / \mathrm{m}^{3}\right)$. However, during various months of the study period, the pollutant's concentration exceeded this reference, reaching its highest mean value $\left(95.8 \mu \mathrm{g} / \mathrm{m}^{3}\right)$ in the month of September 2004. As shown in Table 1, monthly mean $\mathrm{PM}_{10}$ was higher in the autumn and winter $\left(54.7 \mu \mathrm{g} / \mathrm{m}^{3}\right)$, seasons with lower monthly precipitation.

Table 2 shows the results of the adjustments for the two regression models, including the DIC values. The first, called "Model 1", only contains the monthly $\mathrm{PM}_{10}$ measurements as an independent variable (for the month corresponding to the procedures count and the previous month), while "Model 2" contains $\mathrm{PM}_{10}$, low temperature, total precipitation, and season of the year. Although the $95 \%$ CI for $\beta_{2}$ (the parameter associated with monthly $\mathrm{PM}_{10}$ recorded in the month prior to each observation) contains the zero value in both models, it is important for this term to remain in the model in order to avoid autocorrelations between successive values of residuals (verified 
Total monthly procedures (inhalation and nebulization), total monthly precipitation ( $\mathrm{mm})$, low temperature (monthly means, in

$\left.{ }^{\circ} \mathrm{C}\right)$, and monthly mean PM $10\left(\mu \mathrm{g} / \mathrm{m}^{3}\right)$. Ribeirão Preto, São Paulo State, Brazil, 2004-2010.
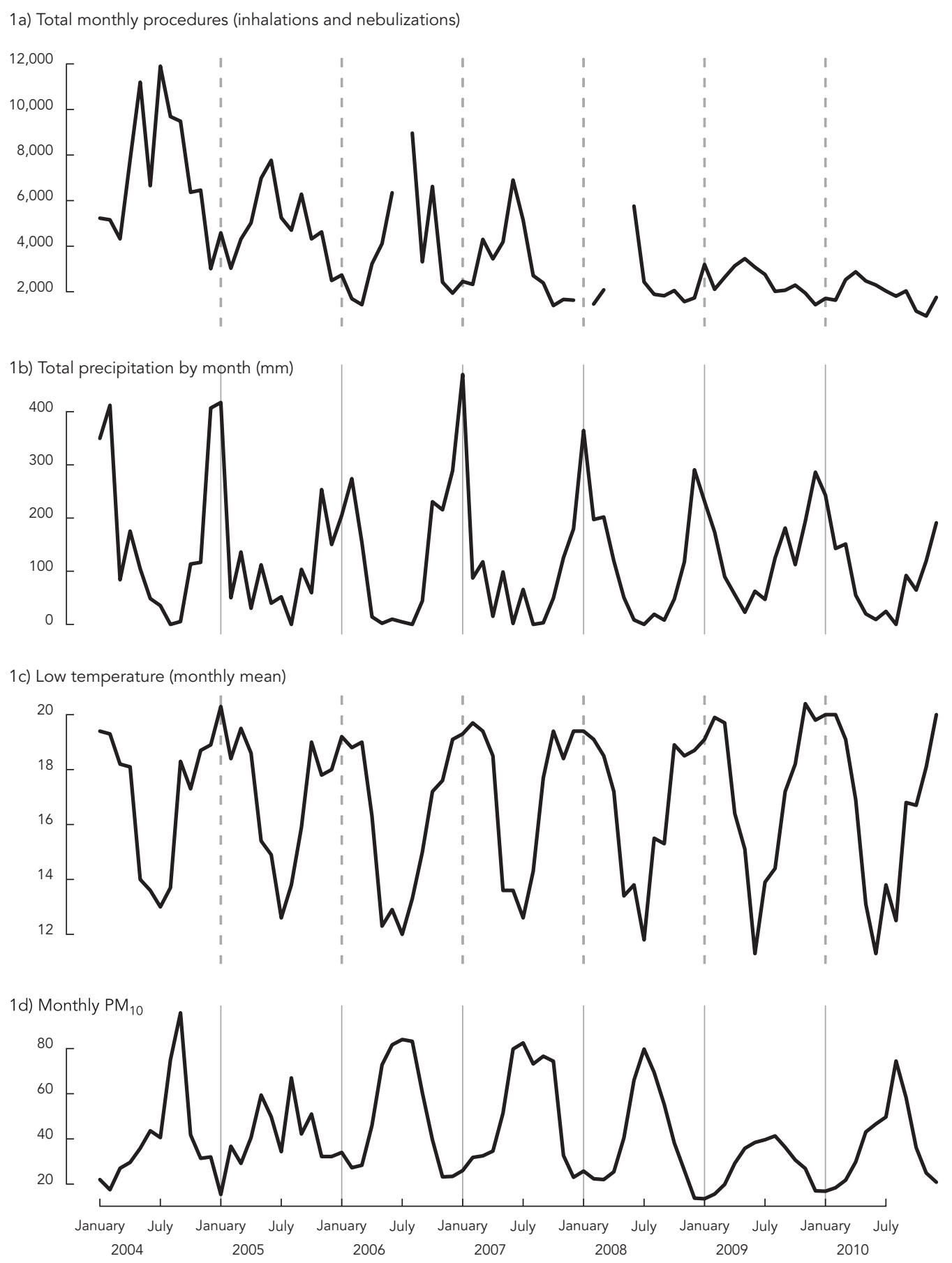
Descriptive statistics according to season of the year. Ribeirão Preto, São Paulo State, Brazil, 2004-2010.

\begin{tabular}{|c|c|c|c|c|c|}
\hline Season/Variable & Mean & SD & Minimum & Median & Maximum \\
\hline \multicolumn{6}{|l|}{ Autumn and winter } \\
\hline Monthly inhalations & $4,753.6$ & $2,798.7$ & 1,807 & 3,453 & 11,900 \\
\hline $\mathrm{PM}_{10}\left(\mu \mathrm{g} / \mathrm{m}^{3}\right)$ & 54.7 & 19.2 & 25.4 & 49.7 & 95.8 \\
\hline Mean low temperature $(\circ \mathrm{C})$ & 14.6 & 2.1 & 11.3 & 13.9 & 18.6 \\
\hline Total precipitation (mm) & 44.4 & 48.3 & 0.0 & 27.4 & 181.2 \\
\hline \multicolumn{6}{|l|}{ Spring and summer } \\
\hline Monthly inhalations & $2,847.6$ & $1,548.2$ & 936 & 2,323 & 6,621 \\
\hline $\mathrm{PM}_{10}\left(\mu \mathrm{g} / \mathrm{m}^{3}\right)$ & 28.0 & 11.0 & 13.5 & 26.5 & 74.4 \\
\hline Mean low temperature $(\circ \mathrm{C})$ & 18.9 & 0.8 & 16.7 & 19.1 & 20.4 \\
\hline Total precipitation (mm) & 194.4 & 110.4 & 47.6 & 176.6 & 469.9 \\
\hline
\end{tabular}

Table 2

Estimates of parameters in the regression model including only the monthly $\mathrm{PM}_{10}$ measurements as the independent variable (Model 1 ) and including the other covariates (Model 2) with their respective $95 \%$ confidence intervals $(95 \% \mathrm{Cl})$ and $\mathrm{DIC}$ (deviance information criterion) values.

\begin{tabular}{|c|c|c|c|c|}
\hline \multirow{3}{*}{$\begin{array}{l}\text { Parameter } \\
\text { Intercept }\left(\beta_{0}\right)\end{array}$} & \multirow{2}{*}{\multicolumn{2}{|c|}{$\begin{array}{c}\text { Model } 1 \\
\text { Estimate }(95 \% \mathrm{Cl})\end{array}$}} & \multirow{2}{*}{\multicolumn{2}{|c|}{$\begin{array}{c}\text { Model } 2 \\
\text { Estimate }(95 \% \mathrm{Cl})\end{array}$}} \\
\hline & & & & \\
\hline & 8.05 & $(7.94 ; 8.14)$ & 8.05 & $(7.95 ; 8.14)$ \\
\hline Monthly $\mathrm{PM}_{10}, \mu \mathrm{g} / \mathrm{m}^{3}\left(\beta_{1}\right)$ & 0.0095 & $(0.003 ; 0.015)$ * & 0.0053 & $(-0.029 ; 0.007)$ \\
\hline Monthly $\mathrm{PM}_{10}$, previous month, $\left(\beta_{2}\right)$ & -0.0029 & $(-0.008 ; 0.003)$ & -0.0027 & $(-0.008 ; 0.003)$ \\
\hline Monthly mean low temperature in ${ }^{\circ} \mathrm{C}\left(\beta_{3}\right)$ & - & - & -0.0111 & $(-0.029 ; 0.007)$ \\
\hline Total precipitation, current month. $\mathrm{mm}\left(\beta_{4}\right)$ & - & - & -0.0009 & $(-0.002 ; 0.201)$ \\
\hline Season - Autumn $\times$ Summer $\left(\beta_{5}\right)$ & - & - & 0.0024 & $(-0.017 ; 0.022)$ \\
\hline Season - Winter $\times$ Summer $\left(\beta_{6}\right)$ & - & - & -0.0558 & $(-0.019 ; 0.019)$ \\
\hline Season - Spring $\times$ Summer $\left(\beta_{7}\right)$ & - & - & -0.0015 & $(-0.021 ; 0.018)$ \\
\hline Time series trend $\left(\beta_{8}\right)$ & -0.0155 & $(-0.019 ;-0.012)$ * & -0.0164 & $(-0.020 ;-0.013)$ * \\
\hline Random effect variance $\left(\sigma^{2}\right)$ & 0.174 & $(0.125 ; 0.237)$ & 0.164 & $(0.119 ; 0.227)$ \\
\hline Deviance information criterion (DIC) & & & & \\
\hline
\end{tabular}

* $95 \% \mathrm{Cl}$ does not contain zero.

graphically). In the adjustment of Model 1, coefficient $\beta_{1}$, associated with monthly mean $\mathrm{PM}_{10}$ in a continuous scale, was estimated at 0.0095 (95\%CI: $0.003 ; 0.015)$, and in the adjustment of Model 2, this coefficient was estimated at 0.0053 (95\%CI: $-0.002 ; 0.013)$. Since the 95\%CI includes zero, it suggests some confounding effects from low temperature, total precipitation, and season of the year on the association between $\mathrm{PM}_{10}$ and number of procedures. In addition, Table 2 shows that Models 1 and 2 have lower DIC values (939.2), suggesting that the addition of these covariates did not improve the fit for the monthly procedure data. Considering Model 2, no effects were seen for the monthly mean low temperature or total precipitation on monthly inhalation/nebulization procedures (the respective 95\%CI include zero, as shown in Table 2). In both models, the estimated effect of the time series trend $\left(\beta_{8}\right)$ is negative, incorporating into the data analysis the downward temporal behavior of the monthly procedure counts depicted in Figure 1.

\section{Discussion}

Air pollution causes thousands of health problems in millions of people worldwide 34,35 , espe- 
cially in individuals with respiratory and cardiovascular diseases 36 . Air pollution accounts for an estimated $5 \%$ of a total of more than 50 million deaths that occur annually in the world 37 . Various studies 9,38,39 have shown direct associations between particulate matter levels and morbidity and mortality rates, which raises warnings concerning the decrease in life expectancy among residents of areas with high accumulation of this pollutant, particularly in large cities. In Brazil, with the use of hydrated alcohol or the anhydrous alcohol/gasoline mixture (22\% alcohol) as fuel in automotive vehicles, the population in large urban areas has felt significant improvements in the environment and health, because such use has led to a decrease in lead compound emissions 40 . However, the growing use of alcohol as fuel led to high growth in sugarcane farming, especially in the interior of São Paulo State. Where sugarcane is grown and processed, the population has suffered from constant burning in the fields 27 , which increases the release of air pollutants, responsible for various health problems 41,42 .

Ribeirão Preto has been heavily affected by this problem in recent decades, not only due to burning in sugarcane fields, but also by fires set by the residents themselves, who believe that burning fallen leaves and branches and the weeds growing on and around their lots, or even household garbage, will solve the problem of accumulated waste around their homes. Although using fire in the forests and land is quite common, it has been condemned for centuries in soil conservation manuals, due to its harmful consequences for the land, since such fires are the main culprits behind climate changes and the resulting destruction of the native plant cover, leaving springs and headwaters unprotected and causing irreversible changes in the rain cycle. Until the 1970s, Ribeirão Preto still had an estimated $22 \%$ of its native forest cover 43 . With the advent of the Proálcool program (aimed at stimulating alcohol production to serve the domestic and foreign market and the country's automotive fuel policy), this area has been reduced to less than $3 \%{ }^{43}$. Although the plant cover to maintain the region's ecological balance is nearly nonexistent, fire is still a threat to the remaining native flora.

Although this study provides evidence that particulate matter has some influence on residents' health in Ribeirão Preto, according to the adjustment in Model 1 shown in Table 2, these results should be interpreted with caution, since the adjustment of Model 2 (Table 2) suggests that this association may derive from confounding caused by temperature, precipitation, or season of the year. The study shows some other relevant limitations when interpreting this association. $\mathrm{PM}_{10}$ levels were obtained from a single monitoring station, which may not represent the municipality homogeneously. Considering that $38.3 \%$ of the population in Ribeirão Preto hold private health plans or insurance 14 , data on the number of inhalations and nebulization procedures obtained from the SIA/SUS database may underestimate a given health situation, since they only cover the outpatient production of public providers (under the SUS). Importantly, many families now have their own nebulizers at home 44 , which would tend to decrease the use of health services for such procedures and thus partially explain the downward trend observed in Figure 1. Although the association between $\mathrm{PM}_{10}$ levels and procedures, expressed by coefficient $\beta_{1}$ in the regression (Model 1, Table 2) is "significant" in a statistical sense in Model 1, the estimated size of the coefficient is relatively small, which does not rule out the possibility of an effect having occurred casually. Numerous studies have shown a weak but "statistically significant" association between particulate matter air pollution and health problems 45 , thereby requiring some care in interpreting the results. Other important variables such as relative humidity were not used here because they were not available in the data sources. Other pollutants such as carbon monoxide (CO), sulfur dioxide $\left(\mathrm{SO}_{2}\right)$, and ozone $\left(\mathrm{O}_{3}\right)$ may be important predictors of diseases and should be included in future studies. 


\section{Resumo}

O objetivo foi investigar os possíveis efeitos da poluição atmosférica nas contagens mensais de procedimentos de inalação/nebulização no Município de Ribeirão Preto, São Paulo, Brasil, no período de 2004 a 2010. Para verificar a relação existente entre os procedimentos e o material particulado $\left(\mathrm{MP}_{10}\right)$ foi assumido um modelo bayesiano de regressão de Poisson, na presença de um fator aleatório que captura a variabilidade extra Poisson entre as contagens. O material particulado mostrou-se associado ao número de inalações/nebulizações, mas a inserção de covariáveis (temperatura, precipitação e estação) sugere um possível efeito de confundimento. Embora outros estudos relacionem o material particulado com o aumento do número de atendimentos em decorrência de morbidades, os resultados do presente trabalho sugerem que estas associações devem ser interpretadas com cautela.

Poluição do Ar; Material Particulado; Infecções Respiratórias

\section{Contributors}

E. Z. Martinez, J. A. Achcar, and E. C. Carneseca participated in all the stages of the study and wrote the article. All the authors revised the article and approved the final version.

\section{Acknowledgments}

The authors wish to thank the FAEPA at the University Hospital of the University of São Paulo (Hospital Universitário da Universidade de São Paulo) in Ribeirão Preto for its financial support. J. A. Achcar and E. Z. Martinez received research productivity grants from $\mathrm{CNPq}$.

\section{References}

1. Cohen JE. Population and climate change. Proc Am Philos Soc 2010; 154:158-82.

2. Abrignani MG, Corrao S, Biondo GB, Renda N, Braschi A, Novo G, et al. Influence of climatic variables on acute myocardial infarction hospital admissions. Int J Cardiol 2009; 137:123-9.

3. Houck PD, Lethen JE, Riggs MW, Gantt DS, Dehmer GJ. Relation of atmospheric pressure changes and the occurrences of acute myocardial infarction and stroke. Am J Cardiol 2005; 96:45-51.

4. Hosseinpoor AR, Forouzanfar MH, Yunesian M, Asghari F, Naieni KH, Farhood D. Air pollution and hospitalization due to angina pectoris in Tehran, Iran: a time-series study. Environ Res 2005; 99: 126-31.

5. Nascimento LF. Air pollution and cardiovascular hospital admissions in a medium-sized city in São Paulo State, Brazil. Braz J Med Biol Res 2011; 44:720-4.

6. Chiarelli PS, Amador-Pereira LA, Saldiva PHN, Ferreira Filho C, Bueno-Garcia ML, Braga ALF, et al. The association between air pollution and blood pressure in traffic controllers in Santo André, São Paulo, Brazil. Environ Res 2011; 111:650-5.

7. Gouveia N, Bremner SA, Novaes HM. Association between ambient air pollution and birth weight in São Paulo, Brazil. J Epidemiol Community Health 2004; 58:11-7.
8. Ignotti E, Hacon SS, Junger WL, Mourão D, Longo $\mathrm{K}$, Freitas S, et al. Air pollution and hospital admissions for respiratory diseases in the subequatorial Amazon: a time series approach. Cad Saúde Pública 2010; 26:747-61.

9. Arbex MA, Souza-Conceição GM, Cendon SP, Arbex FF, Lopes AC, Moysés EP, et al. Urban air pollution and chronic obstructive pulmonary diseaserelated emergency department visits. J Epidemiol Community Health 2009; 63:777-83.

10. Moura M, Junger WL, Mendonça GA, De Leon AP. Air quality and acute respiratory disorders in children. Rev Saúde Pública 2008; 42:503-11.

11. Moura M, Junger WL, Mendonça GAS, De Leon AP. Air quality and emergency pediatric care for symptoms of bronchial obstruction categorized by age bracket in Rio de Janeiro, Brazil. Cad Saúde Pública 2009; 25:635-44.

12. Martins LC, Latorre MRDO, Cardoso MRA, Gonçalves FLT, Saldiva PHN, Braga ALF. Poluição atmosférica e atendimentos por pneumonia e gripe em São Paulo, Brasil. Rev Saúde Pública 2002; 36: 88-94.

13. Jasinski R, Pereira LAA, Braga ALF. Poluição atmosférica e internações hospitalares por doenças respiratórias em crianças e adolescentes em Cubatão, São Paulo, Brasil, entre 1997 e 2004. Cad Saúde Pública 2011; 27:2242-52. 
14. Bittar OJNV, Mendes JDV, Magalhães A. Rede hospitalar no Estado de São Paulo: mapear para regular. São Paulo: Secretaria de Estado da Saúde de São Paulo; 2011.

15. Köeppen W. Climatología: con un estudio de los climas de la tierra. México DF: Fondo de Cultura Económica; 1918.

16. Elias D. Globalização e agricultura: a região de Ribeirão Preto - SP. São Paulo: Edusp; 2003.

17. Miranda MJ, Pinto HS, Zullo Júnior J, Fagundes RM, Fonsechi DB, Calve L, et al. Clima dos municípios paulistas. http://www.cpa.unicamp.br/out ras-informacoes/clima-dos-municipios-paulistas. html (accessed on 20/Dec/2011).

18. Ribeiro H. Queimadas de cana-de-açúcar no Brasil: efeitos à saúde respiratória. Rev Saúde Pública 2008; 42:370-6.

19. Ribeiro H, Assunção JV. Efeitos das queimadas na saúde humana. Estud Av 2002; 16:125-48.

20. Cruz APFN. A tutela penal das queimadas: o problema da cana-de-açúcar no nordeste paulista. Justitia 2000; 62:43-56.

21. Tresmondi ACCL, Beli E, Tomaz E, Piccinini MDLR. Concentração de material particulado inalável MP10 em Espírito Santo do Pinhal - SP. Engenharia Ambiental 2008; 5:133-44.

22. Nascimento LFC, Pereira LAA, Braga ALF, Módolo MCC, Carvalho Jr. JA. Efeitos da poluição atmosférica na saúde infantil em São José dos Campos, SP. Rev Saúde Pública 2006; 40:77-82.

23. Lopes FS, Ribeiro H. Mapeamento de internações hospitalares por problemas respiratórios e possíveis associações à exposição humana aos produtos da queima da palha de cana-de-açúcar no estado de São Paulo. Rev Bras Epidemiol 2006; 9:215-25.

24. Braga ALF, Pereira LAA, Procópio M, André PA, Saldiva PHS. Associação entre poluição atmosférica e doenças respiratórias e cardiovasculares na cidade de Itabira, Minas Gerais, Brasil. Cad Saúde Pública 2007; 23:570-8.

25. Silva AMC, Mattos IE, Freitas SR, Longo KM, Hacon SS. Particulate matter (PM2.5) of biomass burning emissions and respiratory diseases in the south of the Brazilian Amazon. Rev Bras Epidemiol 2010; 13:337-51.

26. Carmo CN, Hacon S, Longo KM, Freitas S, Ignotti E, Ponce de Leon A, et al. Associação entre material particulado de queimadas e doenças respiratórias na região sul da Amazônia brasileira. Rev Panam Salud Pública 2010; 27:10-6.

27. Ferreira-Ceccato AD, Ramos EM, de Carvalho Jr. LC, Xavier RF, Teixeira MF, Raymundo-Pereira PA, et al. Short terms effects of air pollution from biomass burning in mucociliary clearance of Brazilian sugarcane cutters. Respir Med 2011; 105:1766-8.

28. Muchão FP, Silva Filho LVRF. Avanços na inaloterapia em pediatria. J Pediatr (Rio J.) 2010; 86:367-76.

29. Suits DB. Use of dummy variables in regression equations. J Am Stat Assoc 1957, 52:548-51.

30. McCullagh P, Nelder JA. Generalized linear models. 2nd Ed. London: Chapman and Hall/CRC; 1989.

31. Spiegelhalter DJ, Myles JP, Jones DR, Abrams KR. Bayesian methods in health technology assessment: a review. Health Technol Assess 2000; 4:1-130.
32. Lunn DJ, Thomas A, Best N, Spiegelhalter D. WinBUGS - a Bayesian modelling framework: concepts, structure, and extensibility. Stat Comp 2000; 10:325-37.

33. World Health Organization. Air quality guidelines: global update 2005. Copenhagen: World Health Organization; 2006.

34. Seaton A, MacNee W, Donaldson K, Godden D. Particulate air pollution and acute health effects. Lancet 1995; 345:176-8.

35. Schwela D. Air pollution and health in urban areas. Rev Environ Health 2000; 15:13-42.

36. Brook RD, Rajagopalan S, Pope 3rd CA, Brook JR, Bhatnagar A, Diez-Roux AV, et al. Particulate matter air pollution and cardiovascular disease: an update to the scientific statement from the American Heart Association. Circulation 2010; 121:2331-78.

37. World Health Organization. Air pollution. Geneva: World Health Organization; 2000. (Fact Sheet, 187).

38. Cançado JE, Braga A, Pereira LA, Arbex MA, Saldiva PH, Santos UP. Repercussões clínicas da exposição à poluição atmosférica. J Bras Pneumol 2006; 32 Suppl 2:S5-11.

39. Janke K, Propper C, Henderson J. Do current levels of air pollution kill? The impact of air pollution on population mortality in England. Health Econ 2009; 18:1031-55.

40. Companhia de Tecnologia de Saneamento Ambiental. Relatório de qualidade do ar no Estado de São Paulo, 1996. São Paulo: Companhia de Tecnologia de Saneamento Ambiental; 1997.

41. Ribeiro H, Pesquero C. Queimadas de cana-deaçúcar: avaliação de efeitos na qualidade do ar e na saúde respiratória de crianças. Estud Av 2010; 24:255-71.

42. Arbex MA, Böhm GM, Saldiva PH, Conceição GM, Pope $3^{\text {rd }}$ AC, Braga AL. Assessment of the effects of sugar cane plantation burning on daily counts of inhalation therapy. J Air Waste Manag Assoc 2000; 50:1745-9.

43. Borges JRP. O processo de avanço das lavouras de cana-de-açúcar em assentamento rural e seus impactos à saúde humana e ao ambiente - um estudo de percepção de riscos socioambientais. In: VI Congresso de Meio Ambiente da Associação Universidade Grupo de Montevideo. http://www. ambiente-augm.ufscar.br/uploads/A3-007.pdf (accessed on 20/Dec/2011).

44. Zhang L, Costa MG, Avila LH, Bonfanti T, Ferruzzi EH. Asthma related knowledge among parents of asthmatic children at the moment of admission to a specialized service. Rev Assoc Med Bras 2005; 51:342-7.

45. Gamble JF, Lewis RJ. Health and respirable particulate (PM10) air pollution: a causal or statistical association? Environ Health Perspect 1996; 104:838-50.

Submitted on $06 /$ Sep/2011

Final version resubmitted on 22/Dec/2011 Approved on 08/Feb/2012 